J. Japan. Assoc. Min.

Petr. Econ. Geol.

74, 1-15, 1979 .

\title{
PETROLOGICAL STUDY OF THE SOUTH YUBARA QUARTZ GABBROIC MASS, OKAYAMA PREFECTURE, SOUTHWEST JAPAN
}

\author{
MASAKatsu SASADA \\ Geothermal Research Department, Geological Survey of Japan, Kawasaki, 213, Japan.
}

\begin{abstract}
The South Yubara mass is a discordant pluton with exposure of $26 \mathrm{~km}^{2}$, intruding the Sangun metamorphic rocks and the Late Cretaceous volcanic rocks. It is composed of an equi-granular rock facies of quartz gabbroic to granodioritic composition and a porphyritic facies of tonalitic to granodioritic composition. The equi-granular facies is distributed in the inner part of the mass and is enveloped by the porphyritic facies. The latter facies is divided into three sub-facies, type $1 \sim 3$. The porphyritic facies type 1 constitutes the uppermost part of the mass and type 2 and 3 constitute the lateral border. The color index remarkably decreases upwards. Principal constitutent minerals are similar is both facies, that is, they are orthopyroxene, clinopyroxene, homblende, biotite, magnetite, ilmenite, plagioclase, potash feldspar and quartz.

The altitudinal compositional variation of the equi.granular facies and the porphyritic facies type 1 can be explained by the gravitational settling mainly of plagioclase, pyroxene and magnetite in the magma reservoir. It would have been formed before the emplacement to the present place. After the emplacement the magmatic differentiation would have proceeded in the inner part of the intrusive body. The magnetite enrichment and lower Fe/Mg ratio of mafic silicates in the porphyritic facies type 1 and 3 would be attributed to higher oxygen fugacity.
\end{abstract}

\section{INTRODUGTION}

Calk-alkaline volcanic and plutonic rocks of the Cretaceous to Paleogene ages are widely distributed in the Inner Side of Southwest Japan (Fig. 1) (e.g. Ichikawa et al., 1968). The plutonic rocks are divided into the following three belts with respect to metallic ore deposits associated, that is, from south to north, the Ryoke, San-yo and San-in Belts (Kinosaki, 1953; Ishihara, 1971). The South Yubara mass is distributed in the San-in Belt. It is a discordant pluton intruding the Late Cretaceous volcanic rocks and the Sangun metamorphic rocks, and is composed of quartz gabbroic to granodioritic rocks, the texture of which varies from equi-granular to porphyritic.
In the Yubara area the outline of geology was reported by Yamada (1951), and the geology and petrography of the intrusive rocks was described by the present writer (Sasada, 1978). In the present paper the geological occurrence, petrography and petrochemistry of the South Yubara mass are described and processes of differentiation and intrusion of the magma are considered.

The writer wishes to express his thanks to ex-Prof. M. Gorai, Tokyo University of Education for constant guidance in the course of the work and critical reading of the manuscript. He also wishes to express his thanks to Dr. K. Tazaki, Institute for Thermal Spring Research, Okayama University and Mr. H. Kanaya, Geological survey of Japan for the guidance of laboratory 


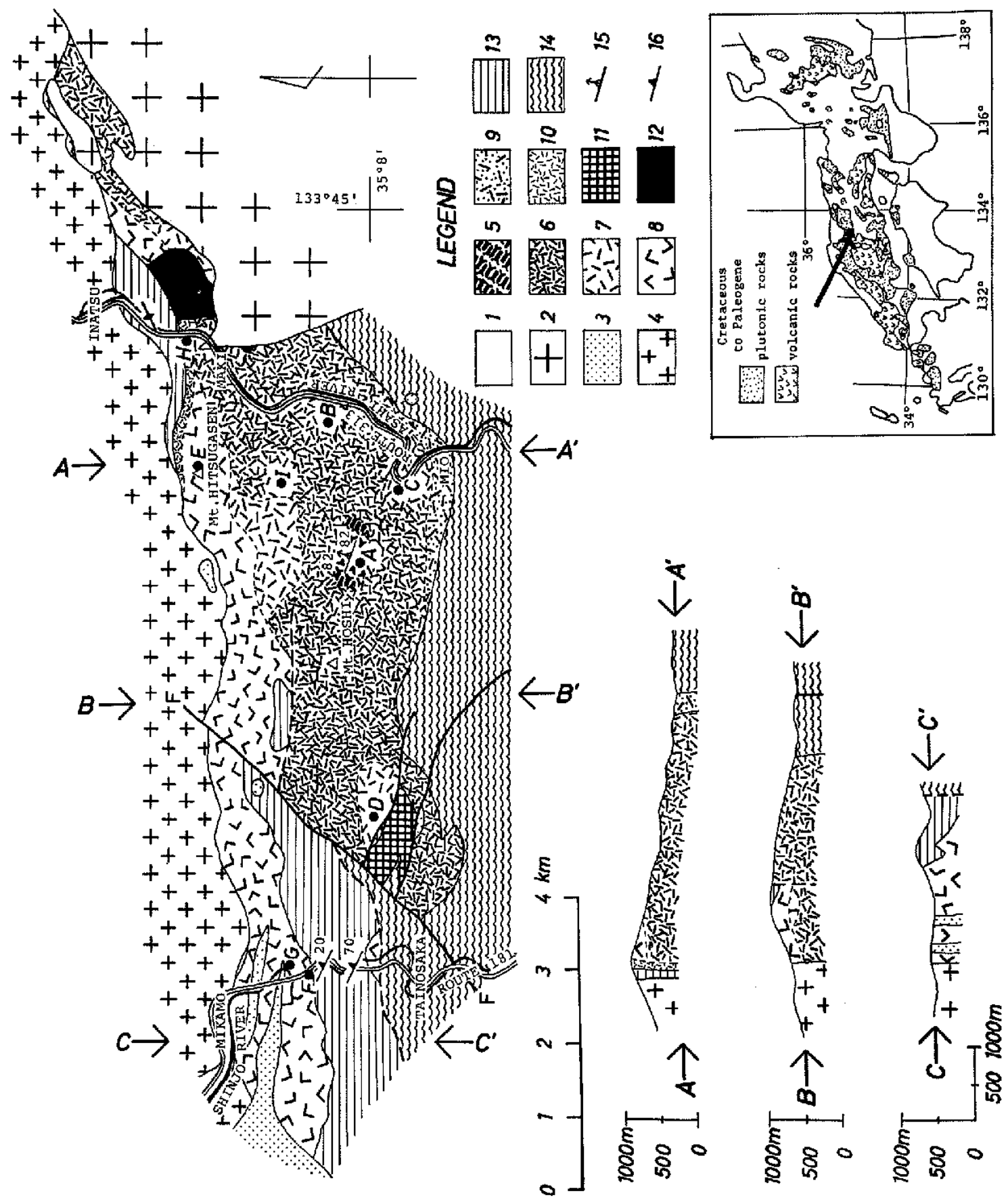


works, and to Mr. N. Yamada, Drs. S. Ishihara and T. Shirahase, Geological Survey of Japan, Dr. H. Honma, Institute for Thermal Spring Research, Okayama University and the members of Petrology Division in Tokyo University of Education for valuable advice and criticism during the work.

\section{Geology}

\section{Wall rocks}

The South Yubara mass is located in the Chugoku backbone mountain area on the north of Okayama Prefecture (Fig. 1). It intrudes into the Sangun metamorphic rocks and the Late Cretaceous volcanic rocks. The Sangun metamorphic rocks were derived from the Palaeozoic formations of PermoCarboniferous ages (Konishi, 1954a; Hashimoto, 1968), which consist of pelitic and psammitic rocks, limestone, chert and basic volcanic rocks. The ultramafic complex composed mainly of serpentinite is interposed in the Palacozoic formations. It also suffered the Sangun metamorphism (Hashimoto, 1968).

The Yamaoku formation of the Lower Jurassic age is distributed in the fault relation with the Sangun metamorphic rocks to the southwest of Mikamo village. It is unconformably overlain by the "Inkstone Series" and related andesitic volcanics (Konishi, 1954b). In the studied area the Late Cretaceous volcanic rocks consist mainly of andesitic to rhyolitic pyroclastics, most of which are welded tuffs.

\section{Intrusive rocks}

Various kinds of intrusive rocks are also distributed in contact with the South Yubara mass (Fig. 1). In the Yubara area the plutonic activity began with the intrusion of basic rocks, then the composition of successive intrusions changed to more acid one. The diskes of basic to intermediate composition were finally intruded. These intrusive rocks can be divided at least into the following five stages on the basis of field evidences (Sasada, 1978).

The intrusive rocks of the first stage are the Inatsu and Tainosaka masses which are small stocks of gabbro. The intrusives of the second stage are the South Yubara mass which is precisely described in this paper and the Kayami mass which is composed mainly of quartz gabbro. The intrusives of the third stage are the North Yubara and Unanji masses composed mainly of granodiorite. The intrusives of the fourth stage are the leucocratic granophyres. The coarse-grained biotite granite of the Suribachiyama mass seems to have intruded at the third or fourth stage. The last stage of the magmatism is represented by the intrusion of diabase and porphyrite dikes (Sasada, 1978).

\section{South Yubara mass}

The South Yubara mass has areal exposure of $26 \mathrm{~km}^{2}$ and is elongated in $\mathrm{EW}$ direction. It is composed of the equigranular facies of quartz gabbroic to granodioritic composition and the porphyritic facies mainly of tonalitic to granodionitic

Fig. 1 Geological map and geological section of the South Yubara mass.

1: Allnvial deposits, 2: Suribachiyama biotite granite mass, 3: Leucocratic granophyre masses, 4:

North Yubara granodiorite mass, 5-10: South Yubara mass (5: Coarse-grained equi-granular facies, 6: Medium-grained equi-granular facies (quartz gabbro and tonalite), 7: ditto (granodiorite), 8: Porphyritic facies type 1, 9: Porphyritic facies type 2, 10: Porphyritic facies type 3), 11: Tainosaka gabbro mass, 12 : Inatsu gabbro mass, 13: Volcanic rocks (12-13: Late Cretaceous to Early Paleogene), 14: Sangun metamorphic rocks, 15: Foliation and lineation of the coarse-grained equi-granular facies, 16: Foliation of the welded tuff. 
composition.

This mass is divided into two parts by the fault F( Fig. 1). In the eastern side of the fault $F$, the contact plane with the Sangun metamorphic rocks and the volcanic rocks generally dips steeply outwards. The volcanic rocks construct the roof on the mass to the north of Mt. Hoshi and the septum between the South Yubara and the North Yubara masses in the vicinity of Inatsu (Fig. 1). The intrusive breccia is distributed in the periphery of the mass in contact with the volcanic septum.

In the western side of the fault $F$ this mass intrudes into the volcanic rocks only. The small stocks and dikes of porphyritic granodiorite in the wall rocks, the offshoots from the South Yubara mass, suggest the extension of this mass below the volcanic pile there (Fig. 1). Judging from the arrangment of the lithological facies of both sides of the fault $F$, it is a right lateral pivotal fault, and the relatively deep part of the mass would be exposed in the south of the eastern side.

\section{Contagt Aureole}

The contact aureole develops in the narrow zone from the contact plane. Biotite is recrystallized in the pelitic hornfels in the distance $150 \mathrm{~m}$ from the contact. The mineral assemblage of pelitic hornfels derived from the black schist of Sangun metamorphic rocks is generally potash feldsparplagioclase-quartz-biotite-garnet-iron ore. That of the basic hornfels derived from the green schist is clinopyroxene-hornblendebiotite-plagioclase-iron ore. On the other hand, that of the thermally metamorphosed andesitic volcanic rocks is clinopyroxenehornblende-biotite-epidote-plagioclase-quartz-iron ore. That of the rhyolitic volcanic rocks is potash feldspar-plagioclase-quartzbiotite. These mineral assemblages of hornfelsic rocks are those of amphibole hornfels facies (Reverdatto, 1970).

\section{EQUI-GRANULAR FAGIES}

The equi-granular facies is composed of medium- and coarsengrained parts. The medium-grained part is widely distributed, the coarse-grained one having limited distribution to the east of Mt. Hoshi (Fig. 1). The field relation between them is gradational.

\section{Medium-grained part}

The medium-grained part is composed of quartz gabbro (Fig. 2-2), tonalite and granodiorite. The field relations between them are gradational. The granodiorite is generally distributed at the higher level.

Principal constituents of quartz gabbro and tonalite are orthopyroxene, clinopyroxene, hornblende, biotite, magnetite, ilmenite, plagioclase, potash feldspar and quartz. Those of the granodiorite are similar to them, except pyroxene which is often absent in it. Accessory minerals are zircon, apatite, pyrite and chalcopyrite. Coarse-grained part

The coarse-grained part is made up of quartz gabbroic rocks characterized by the preferential arrangement of pyroxene and plagioclase (Fig. 2-1). The dips of foliation and lineation are very steep and the strike of the former is harmoneous with the direction of elongation of the mass (Fig. 1).

Principal constitutents are similar to those of the medium-grained quartz gabbro. Pyroxene is more abundant in this part (up to 20 percent) than in the mediumgrained one (up to 12 percent). On the other hand hotnblende is often absent in this part. 

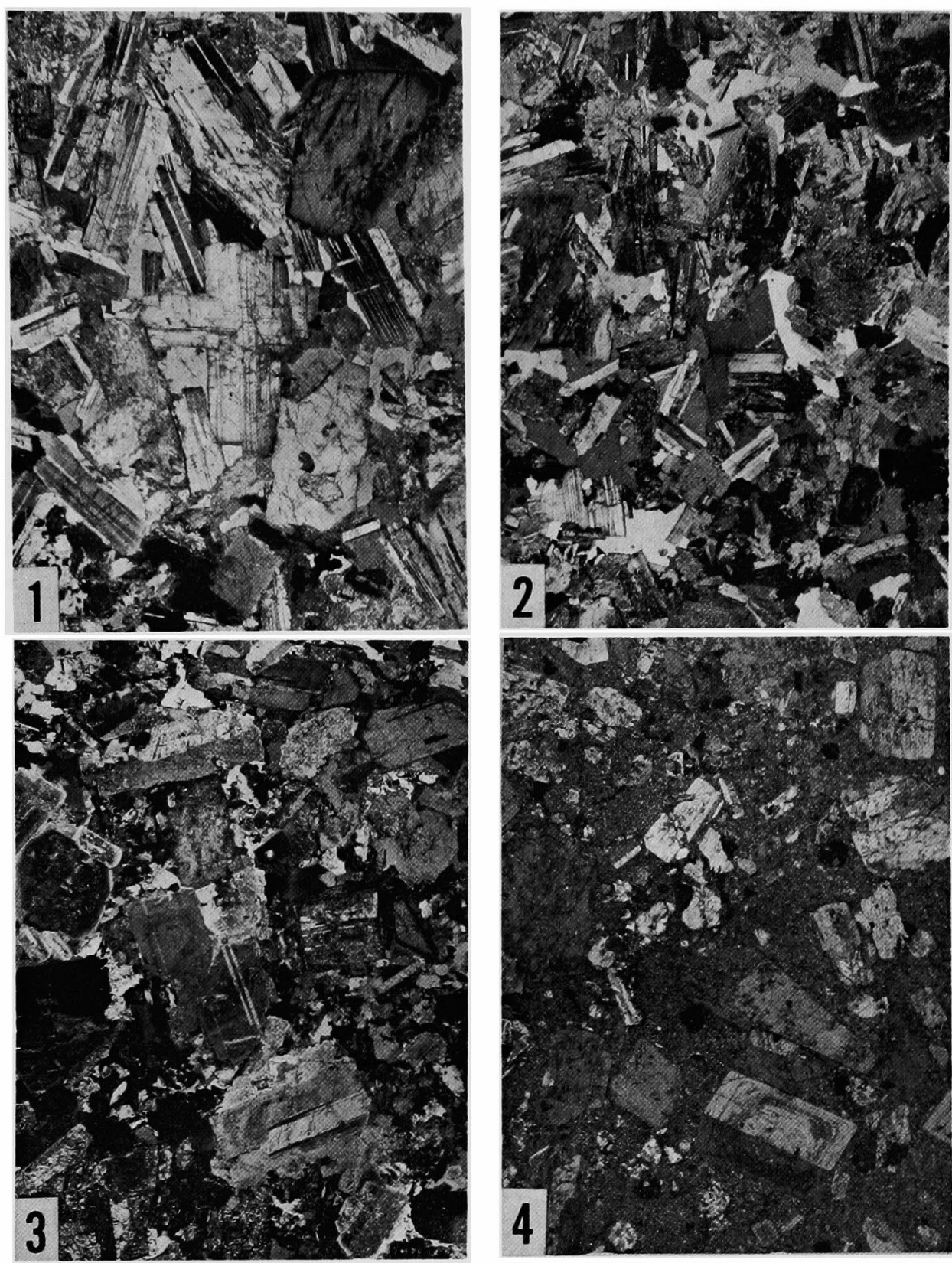

\section{$5 \mathrm{~mm}$}

Fig 2 1: Coarse-grained equi-granular facies. Quartz gabbro (chemically analyzed sample: A). 2: Medium-grained equi-granular facies. Quartz gabbro (B), 3: Porphyritic facies type 1 (F), 4 : Porphyritic facies type $3(\mathrm{H})$. 


\section{Aplite}

The aplite and pegmatite are found only in the medium-grained equi-granular facies. The former generally occurs as a small vein several centimeters wide. It is a slightly pinkish fine-grained rock. Principal constitutents are plagioclase, potash feldspar, quartz, biotite and magnetite.

\section{Enclaves}

Various kinds of enclaves are included in the South Yubara mass. They are generally present as ovoidal to angular ones several centimeters in diameter. They are conveniently divided into the following five groups, that is, thermally metamorphosed Sangun metamorphic rocks, andesitic volcanic rocks, fine-grained gabbroic rocks, orbicular gabbro and medium-grained peridotite. The gabbroic to ultrabasic enclaves are only found in the equi-granular facies.

\section{Porphyritic Factes}

The porphyritic facies is further divided into three sub-facies on the basis of occurence and petrography. They are conveniently called the porphyritic facies type 1,2 and 3 in the present paper.

\section{Type 1}

The porphyritic facies type 1 is a greenish grey-colored granodionitic rock (Fig. 2-3). This type is distributed in the western side of the fault $F$ and in the altitudinal higher level in the eastern side (Fig. 1). There is the roof of volcanic rocks on this type to the north of Mt. Hoshi. The field relation between this type and the equigranular facies is gradational. These evidences indicate that this type constitutes the uppermost part of the intrusive body.

Principal constituents are the same as those of the medium-grained equi-granular facies. Phenocrystic minerals are plagioclase, clinopyroxene and othopyroxene, and micro- phenocrystic minerals are hornblende, biotite, magnetite and ilmenite. Quartz and potash feldspar are present generally as micrographic intergrowth. Accessory minerals are sphene, apatite, zircon, pyrite and chalcopyrite. Sphene is only present in the porphyritic facies type 1 and 3 . This type is generally altered, chlorite, epidote, sericite and calcite being observed all over the area.

Type 2

The porphyritic facies type 2 is distributed along the southern margin of the mass. This type is a slightly porphyritic rock of tonalitic composition. The field relation between this type and the mediumgrained equi-granular facies is gradational. Principal constituents and color index are similar to those of the adjacent equigranular facies. Micrographic intergrowth of quartz and potash feldspar also deve lops. These evidences indicate that this type constitutes the southern flank of the intrusive body.

Type 3

The porphyritic facies type 3 is distributed along the northern margin in contact with the intrusive breccia and volcanic rocks constructing the septum. The field relations between this type and the adjacent equi-granular facies and the type 1 are not confirmed, but the abrupt change of the rock facies is observed between this type and the equi-granular facies with lacking of outcrop in short distance along the route No. 313 in the vicinity of Maki. This type has a chilled marginal facies (Fig. 2-4) against the intrusive breccia. Principal constituents and phenocrystic minerals are the same as those of the porphyritic fcies type 1 .

\section{MODE}

Modal ratios of felsic minerals are 
plotted on Fig. 3. Intrusive rocks are classified according to the system proposed by IUGS subcommission (Streckeisen, 1973). The medium-grained equi-granular facies is plotted on the areas of granodiorite, tonalite and quartz gabbro. The coarse-grained

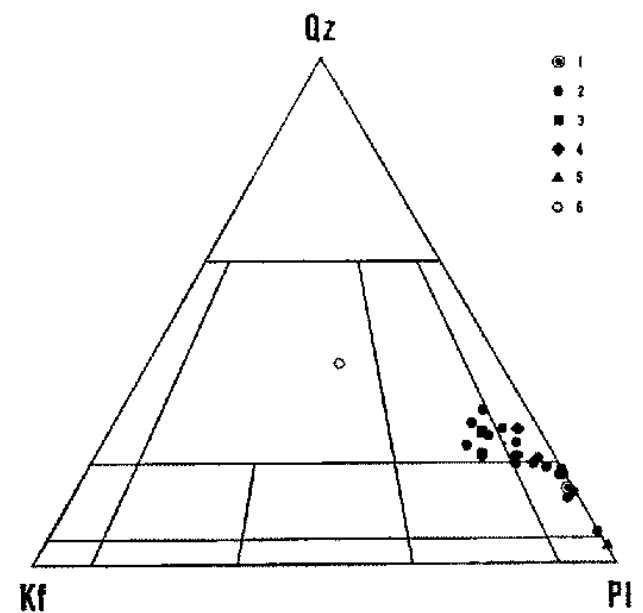

Fig. 3 Modal quartz (Qz)-potash feldspar (Kf)plagioclase $(\mathrm{Pl})$ diagram.

1: Coarse-grained equi-granular facies, 2 : Medium-grained equi-granular facies, 3: Porphyritic facies type 1, 4: Porphyritic facies type 2, 5: Porphyritic facies type 3, 6: Aplite. part is superimposed on the plagioclase-rich part of the medium-grained one. The porphyritic facies type 1, 2 and 3 are plotted on the areas of granodiorite, tonalite and gabbro respectively.

Color index varies not only laterally but also altitudinally except for the porphyritic facies type 3 . Color index is higher than 30

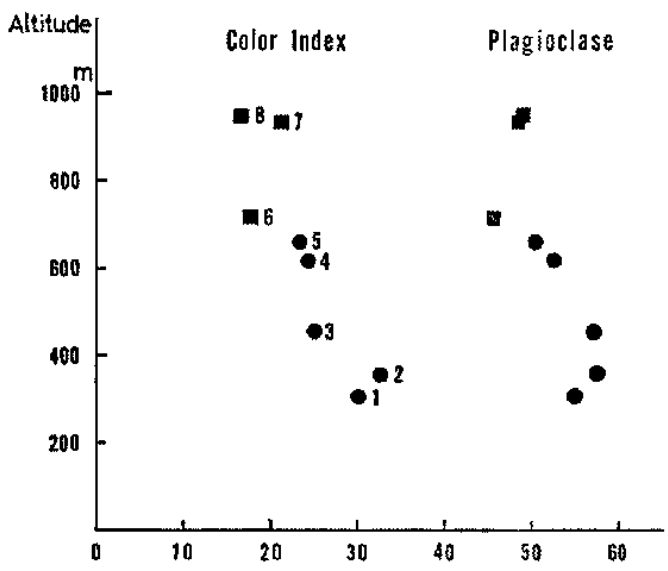

Fig. 5 Altitudinal variation of color index and mode of plagioclase. Numbers correspond to those of Fig. 4. Solid circle: Mediumgrained equi-granular facies, Solid square: Porphyritic facies type 1 .

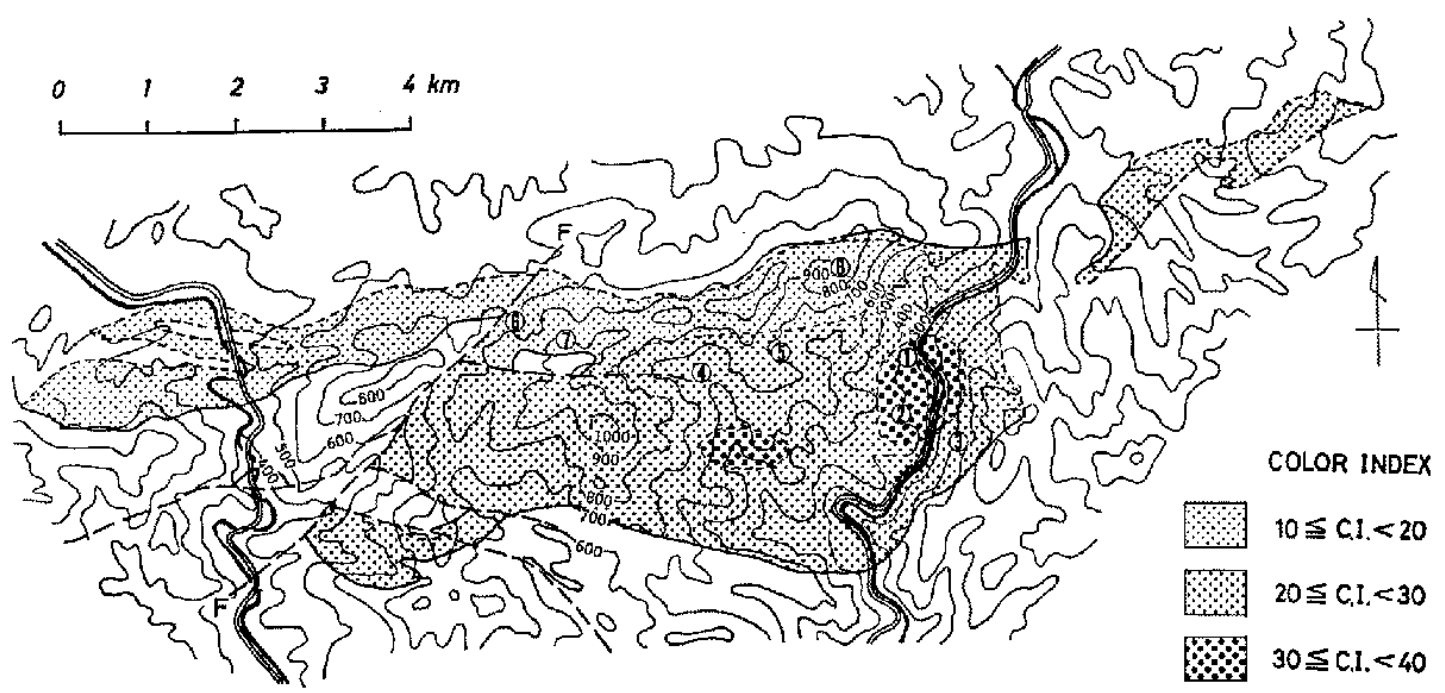

Fig, 4 Variation of color index in the South Yubara mass. 
in the inner part along the Asahi River and in the coarse-grained equi-granular facies (Fig. 4). On the other hand it is lower than 20 in the altitudinal higher level to the east of fault F. It is also low all over the area to the west of the fault (Fig. 4). Color index and mode of plagioclase decrease upwards in the eastern side of fault $F$ as shown in Fig. 5.

\section{Plagioglase}

Plagioclase in the equi-granular facies occurs as subhedral to euhedral tabulets, ranging from $0.5 \mathrm{~mm}$ to $2.0 \mathrm{~mm}$ long. In the porphyritic facies phenocrystic plagio- clase occurs as euhedral to subhedral or resorbed crystals, ranging from $0.5 \mathrm{~mm}$ to $2.5 \mathrm{~mm}$ long. A large crystal in the equigranular facies and phenocrystic one in the porphyritic facies have a similar zoning pattern. They have a resorbed core of bytownite to labradorite, normally zoned mantle of labradorite often enclosing minute crystals of clinopyroxene and normally zoned rim of andesine to oligoclase. The superimposition of oscillatory zoning is usually observed in core and mantle parts.

The average anorthite content of core part is almost constant over the area of the mass, whereas that of rim part is variable
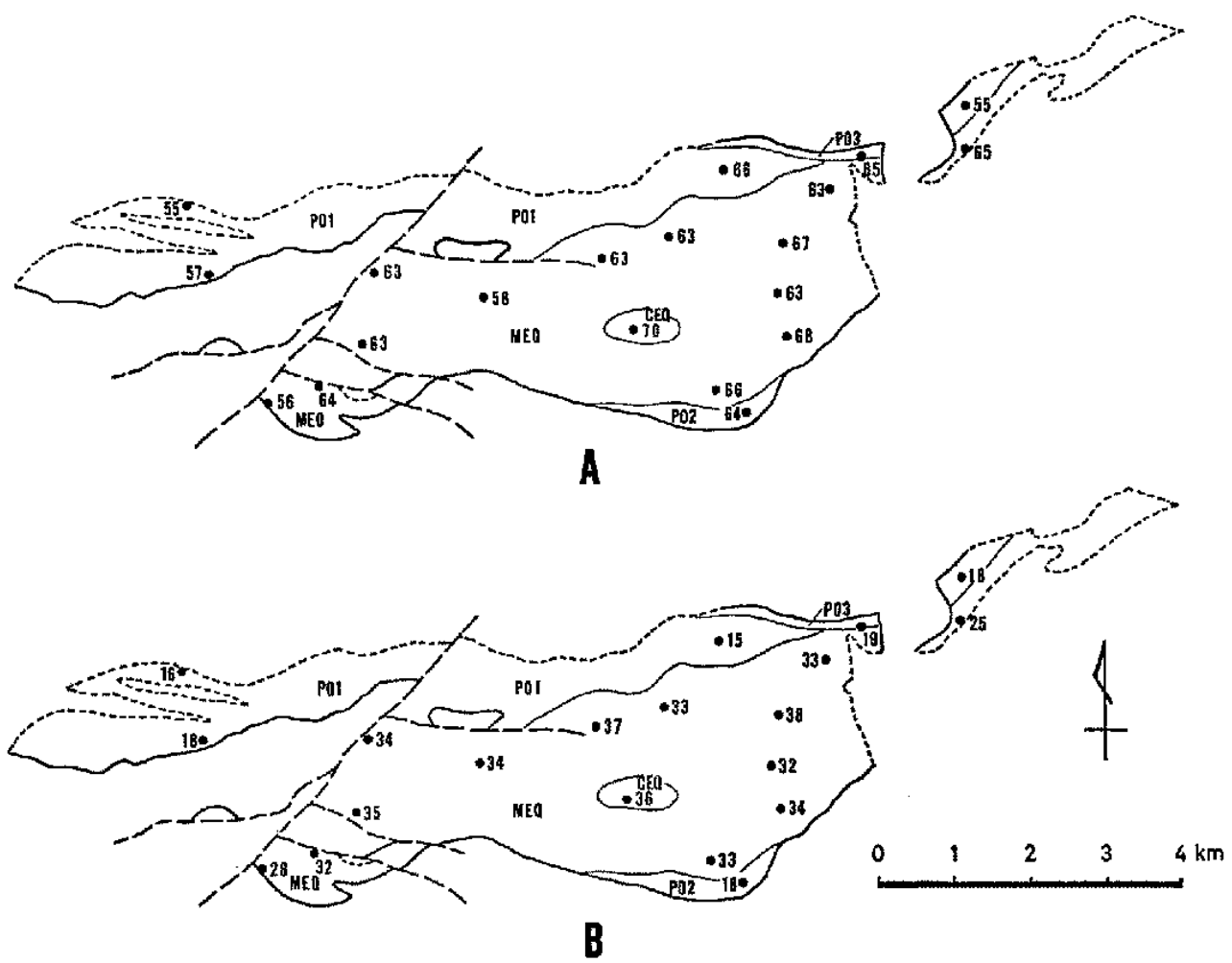

Fig. 6 Variation of An content of plagioclase in the South Yubara mass.

A: core, B: rim.

An content was determined by measuring the greatest extinction angle in the zone perpendicular to (010) and plotting the diagram for low-temperature plagioclase (Suwa et al., 1974). The figure is represented by average of ten grains. Abbreviations: CEQ: Coarse-grained equi-granular facies, MEQ: Medium-grained equi-granular facies, PO1: Porphyritic facies type 1, PO2: Porphyritic facies type 2, PO3: Porpyritic facies type 3. 
(Fig. 6). Generally the latter is andesine in the equi-granular facies and oligoclase in the porphyritic facies (Fig. 6).

The similarities of the zoning pattern and anorthite content of core part in both facies suggest that the equi-granular and porphyritic facies would closely relate to each other genetically. On the other hand the compositional difference of rim part between them would be able to be explained by the difference of crystallization environment at the later magmatic stage. The sodic rim observed in the porphyritic facies would be attributed to more fractional crystallization due to rapid cooling and/or higher content of alkaline components in the residual liquid.

\section{Mafic Minerals}

Pyroxene, hornblende and biotite were chemically analyzed by the electron probe microanalyzer JXA-5A in the Institute for Thermal Spring Research, Okayama University. The data were corrected by the method proposed by Bence and Albee (1968). Pyroxene

Clinopyroxene generally occurs as a euhedral crystal in the porphyritic facies and as an anhedral crystal enclosed with hornblende in the equi-granular facies. It is often replaced by actinolitic amphibole. Orthopyroxene is generally present as a slightly rounded prismatic crystal often enclosed with hornblende in the equigranular facies. In the porphyritic facies most of it is altered to secondary minerals. The Fe/Mg ratio of clinopyroxene is higher in the equi-grantular facies than in the porphyritic facies (Fig. 7). Clinopyroxene ranges from augite to salite (Fig. 7). Such Ca-rich clinopyroxenes have been reported from calc-alkaline plutonic suites (Best and Mercy, 1967; Tainosho, 1974). Orthopyroxene is hypersthene and its $\mathrm{Ca}$ content is lower than those of the tholeitic series (Fig. 7).

\section{Hornblende.}

Hornblende is present as anhedral to subhedral green crystals in the equi-granular

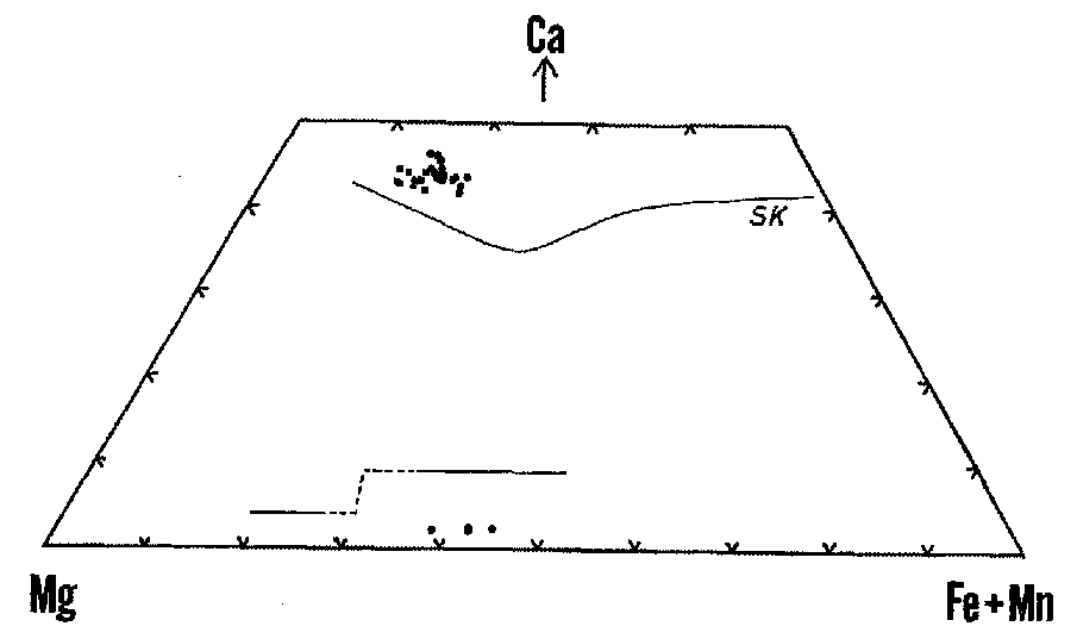

Fig. 7 Compositions of pyroxenes from the South Yubara mass. Solid circle: Equi-granular facies, Solid square: Porphyritic facies type 1, Solid triangle: Porphyritic facies type 3. SK: Pyroxenes from the Skaergaard Intrusion (Brown and Vincent, 1963). 
facies and as subhedral to euhedral prismatic brownish green crystals in the porphyritic facies. It often encloses pyroxene and $\mathrm{Fe}$ Ti oxides in both facies. It has the chemical composition between tremolite and edenite as shown in Fig. 8. The $\mathrm{Fe} / \mathrm{Mg}$ ratio of homblende is higher in the equi-granular facies than in the porphyritic facies (Fig. 8). Biotite

Biotite occurs as a subhedral brownish crystal and sometimes encloses $\mathrm{Fe}-\mathrm{Ti}$ oxides. It is often altered to chlorite and other secondary minerals, fresh one being rarely found especially in the porphyritic facies.
Individual grains are chemically homogeneous. The average $\mathrm{Fe} /(\mathrm{Fe}+\mathrm{Mg})$ ratio is plotted on Fig. 12.

\section{Magnetic Susceptibility}

Magnetic susceptibility depends mainly on the volume ratio of $B$ phase of $\mathrm{Fe}-\mathrm{Ti}$ oxide, although various kinds of magnetic minerals are contained in the granitic rocks (Kanaya and Ishihara, 1973). It was measured by BISON magnetic susceptibility meter Model 3101 in the Geological Survey of Japan. The areal variation in terms of $\chi$ values is shown in Fig. 9. It is generally
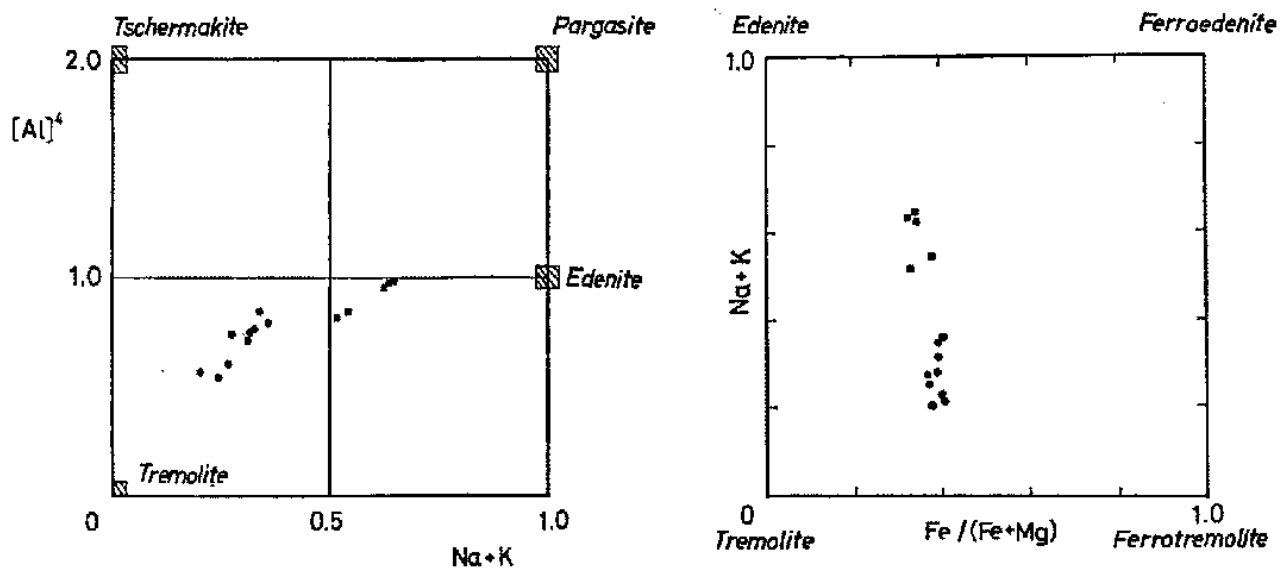

Fig. 8 Compositions of hornblende from the South Yubara mass. Solid circle: Equi-granular facies, Solid square: Porphyritic facies type 1 .
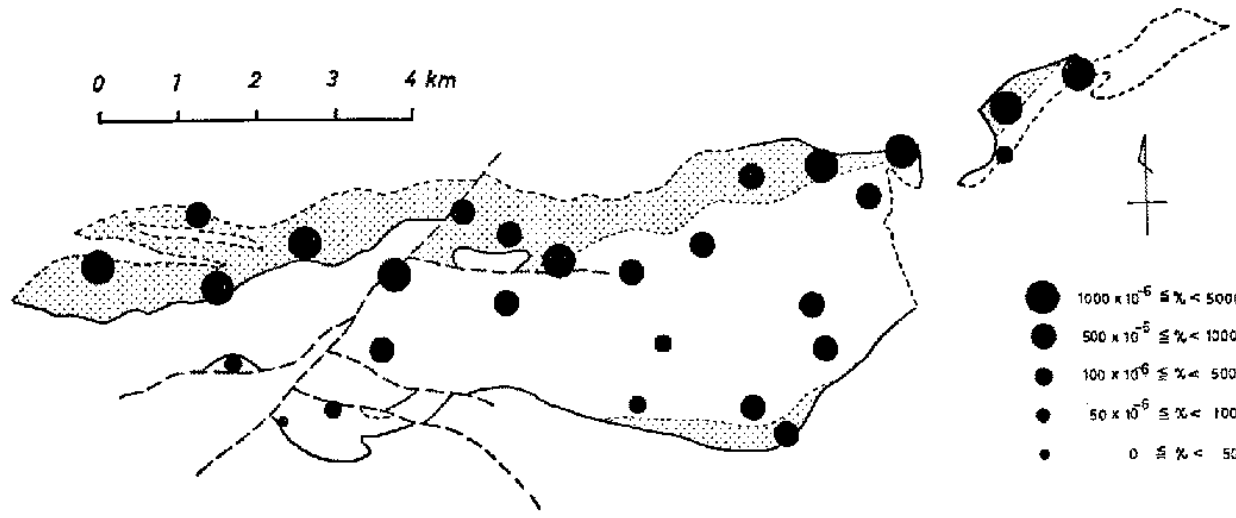

Fig. 9 Variation of magnetic susceptibility in the South Yubara mass.

Dotted area: Porphyritic facies. 
higher in the porphyritic facies in contact with the volcanic rocks than in the equigranular facies. The variation is independent of the color index of the intrusive rocks (Figs. 4, 9).

\section{Chemistry of Whole RoGKS}

Representative samples from each facies were chemically analyzed by the following methods. $\mathrm{SiO}_{2}$ was determined by gravimetric method, $\mathrm{TiO}_{2}, \mathrm{MnO}$ by colorimetry, $\mathrm{Al}_{2} \mathrm{O}_{3}, \mathrm{Fe}_{2} \mathrm{O}_{3}, \mathrm{MgO}$ and $\mathrm{CaO}$ by titration using EDTA, $\mathrm{Na}_{2} \mathrm{O}, \mathrm{K}_{2} \mathrm{O}$ by flame photometry and $\mathrm{FeO}$ by titration using potassium permanganate. The results of analysis are listed in Table 1 and CIPW norms are also listed in the same table.

The chemical composition of coarsegrained equi-granular facies (analyzed smaple A) is the most basic in this mass. The medium-grained grarodiorite (sample D) is more differentiated than the other equigranular rocks ( $\mathrm{B}$ and $\mathrm{C}$ ). The porphyritic facies type 1 is gnerally more differentiated than the equi-granular facies, that is, the former is deficient in total $\mathrm{FeO}, \mathrm{MgO}, \mathrm{CaO}$ and abundant in $\mathrm{SiO}_{2}$ and alkaline components. The ferric/ferrous ratio is generally higher in the porphyritic facies than in the equi-granular facies.

\section{Considerations}

\section{Altitudinal variation}

The present erosion level of the South Yubara mass is upper and uppermost parts of an intrusive body. The porphyritic facies type 1 constitutes the uppermost part and the medium-grained equi-granular facies is distributed below the former. The relation between them is gradational and they have a similar mineral assemblage. The zoning pattern and core composition of

Table 1 Chemical composition and CIPW norms of the intrusive rocks of the South Yubara mass.

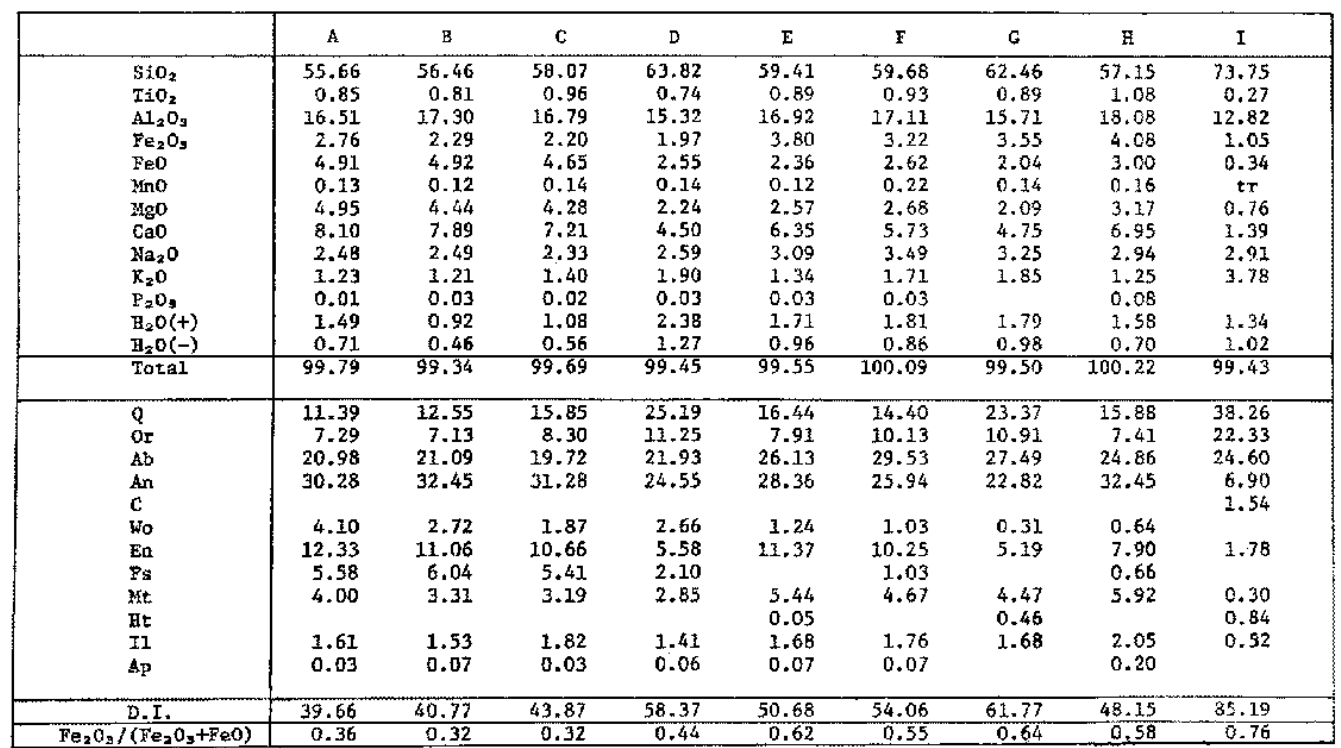

A: Quartz gabbro from the coarse-grained equi-granular facies, B: Quartz gabbro from medium-grained equi-granular facies, $C$ : Tonalite from medium-grained equi-granular facies, D: Granodiorite from medium-grained equi-granular facies, E G : Porphyritic rocks from porphyritic facies type 1, H: Porphyritic rock from porphyritic facies type 3, I: Aplite. Alphabet corresponds to that in the geological map (Fig. 1). Analyst: M. Sasada. 
plagioclase also common to each facies. Color index and mode of plagioclase decrease upwards from the medium-grained equigranular facies to the porphyrtic facies type 1. The porphyritic facies type 1 is also more differentiated than the mediumgrained equi-granular facies in chemical composition. These evidences suggest that they would have been upper and uppermost parts of a certain altitudinally differentiated magma reservoir.

Pyroxene, plagioclase and Fe-Ti oxides would be minerals which crystallized at the early stage on the basis of mineral assemblage of phenocrysts in the porphyritic facies and mutual relationships of constituent minerals in the equi-granular facies. The differentiation trend on the AFM variation diagram (Fig. 10) would be able to be explained by the fractionation of minerals with lower $\mathrm{Fe} / \mathrm{Mg}$ ratio than whole rock (Fig. 12). Taking account of the crystallization order of mafic minerals, the fractionation of pyroxene and magnetite would reasonably explain the chemical variation. With respect to felsic components, the differentiation trend $I$ on the normative feldspar diagram (Fig. 11) would be due to the fractionation of calcic plagioclase.

Thus the altitudinal variation would have been formed by the gravitational settling of pyroxene, magnetite and plagioclase. The cumulative texture is, however, not observed in the exposed part of the mass. The porphyrtic facies type 1 would have been a liquid-rich uppermost part of the differentiated magma reservoir and the medium-grained equi-granular facies would have been a relatively crystal-rich part below the former.

Mait processes of the above mentioned differentiation of the magma would have occurred before the emplacement to the

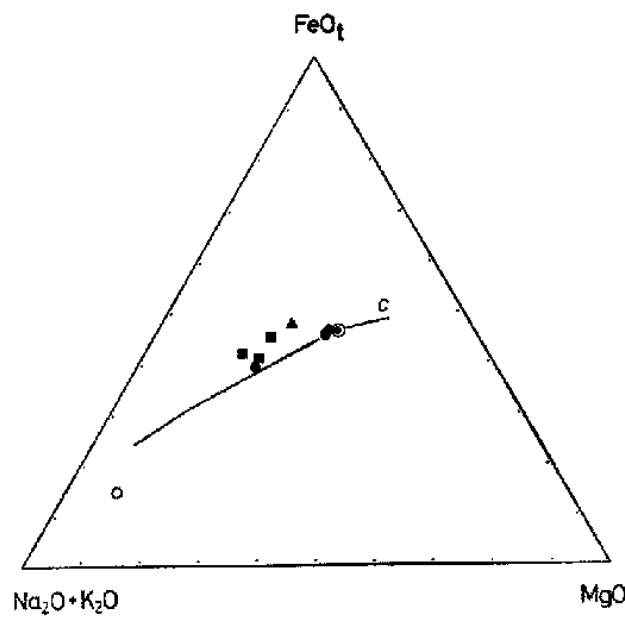

Fig. 10 AFM variation diagram. Symbols are the same as those in Fig. 3. C: Averaged gabbro, diorite, granodiorite and granite after Nockolds (1954).

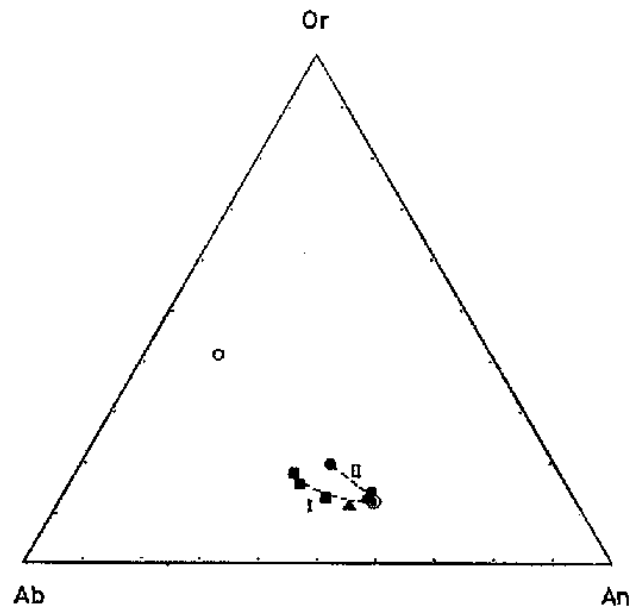

Fig. 11 Normative Or-Ab-An diagram. Symbols are the same as those in Fig. 3. Trend I represents the differentiation before the emplacement to the present place. Trend II represents differentiation after the emplacement.

present place. As the porphyritic facies type 1 shows the texture which was formed by the rapid cooling, it must keep the chemical composition of the uppermost part of the magma at the time of emplacement. The porphyritic facies type 2 , which 
constitutes the southern flank of the mass, has a similar composition to the adjacent medium-grained equi-granular facies. Inasmuch as the upper margin is more acid than the lateral one, it is considered that the altitudinally differentiated magma would have intruded into the present place.

Oxygen fugacity

Magnetic susceptibility and ferric/ ferrous ratio of the whole rock samples indicate that the porphyrtic facies type 1 and 3 are more abundant in magnetite than the equi-granular facies. On the other hand mafic silicates are more $\mathrm{Mg}$-rich in the porphyrtic facies type 1 and 3 than the equi-granular facies (Fig. 12). High oxygen fugacity promotes crystallization of magnetite which depleted the magma in iron and prevents iron enrichment of silicates (Forder, 1971; Hewins, 1974). Experimental studies also show that $\mathrm{Fe} / \mathrm{Mg}$ ratio of pyroxene and amphibole depends on oxygen fungacity (Spiedel and Osborn, 1967; Mysen and Boettcher, 1975; Popp et al., 1977). Therefore the magnetite enrichment and lower $\mathrm{Fe} / \mathrm{Mg}$ ratio of mafic silicates in the porphyritic facies type 1 and 3 would be attributed to higher oxygen fugacity at the time of crystallization. It would be also attributed to this condition that sphene is only present in the porphyritic facies type 1 and 3 , because it is considered to be stable in more oxidized facies (Wones, 1966). The problem why the porphyritic facies in contact with the volcanic rocks crystallized in the condition of higher oxygen fugacity still remain unsolved.

\section{Differentiation after emplacement}

After the emplacement to the present place, the magmatic differentiation would have proceeded in the inner part of the intrusive body. Analyzed sample D which was collected from the medium-grained equigranular facies at the higher level is plotted out of the trend $I$ on the normative feldspar diagram (Fig. 11). The deviation to more orthoclase-rich area (trend II) would be able to be explained by the fractionation of plagioclase which is more sodic than the plagioclase that controlled the trend I. Considerable amount of andesine mantling the suspending plagioclase would have played an important role in this differentiation process.

In the equi-granular facies, the coarsegrained part is distributed in the central area. It is well foliated rock which is more abundant in pyroxene than in the mediumgrained part. Although it is the most basic facies, the steep foliation and lineation is

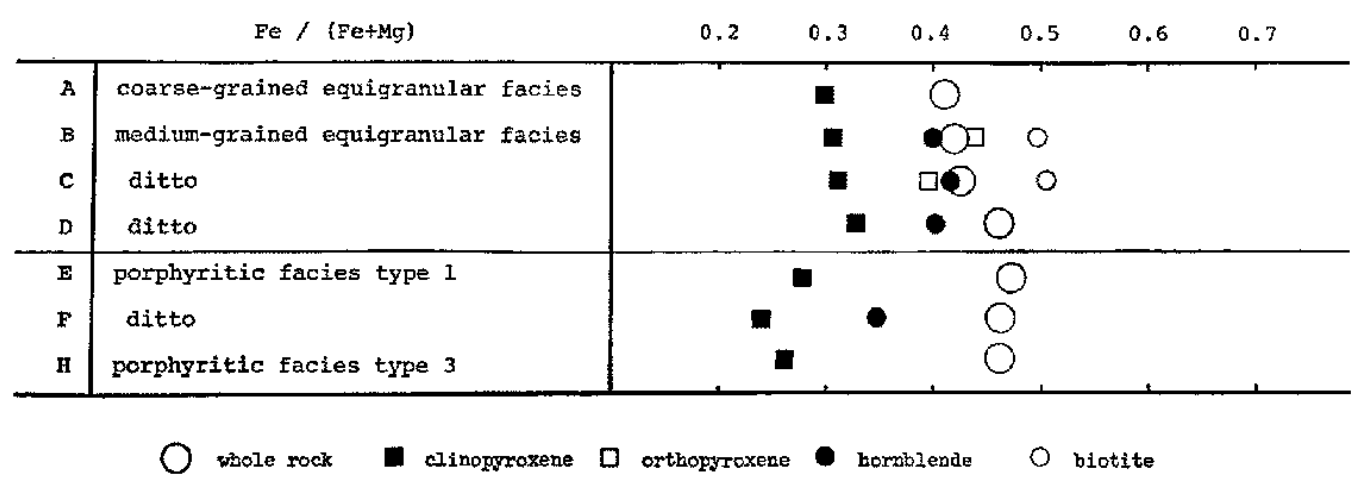

Fig. $12 \mathrm{Fe} /(\mathrm{Fe}+\mathrm{Mg})$ ratio of whole rock and mafic silicates. Alphabet corresponds to that in Table 1. 
not consistent with the idea that this facies is the cumulate of the magma forming the South Yubara mass. Structural factors and modal composition rather suggest that the upward convective flow of crystal-rich magma from the lower part of the reservoir at the later magmatic stage.

The aplite is also differentiation products after the emplacement. It is only found in the medium-grained equi-granular facies. It has the most differentiated chemical composition (Table 1) and would be a residual liquid squeezed from almost consolidated medium-grained equi-granular facies.

\section{Early intrusion}

The porphyritic facies type 3 is distributed along the northern margin with a little altitudinal compositional variation. Judging from the mode of occurrence and texture, it would have been formed as a dike-like intrusion before the emplacement of the main part. As previously mentioned geological and petrographical evidence suggest that the this type would have been derived from the magma common to the other facies. Thus the porphyritic facies type 3 may be considered to represent the earlier stage product of the magmatic differentiation.

\section{REFERENGES}

Bence, A.E. and Albee, A.L. (1968) Empirical correction factors for the electron microanalysis of silicates and oxides. Jour. Geol., 76, 382-403.

Best, M.G. and Mercy, E.L.P. (1967) Composition and crystallization of mafic minerals in the Guadalupe igneous complex, California. Am. Min., 52, 436-474.

Brown, G.M. and Vincent, E.A. (1963) Pyroxene from the late stages of fractionation of the Skaergaard intrusion, East Greenland. Jour. Petrol., 4, 175-197.

Fodor, R.V. (1971) Fe content in pyroxenes from a calc-alkalic volcanic suite, New Mexico, U.S. A.. Earth Planet. Sci. Lett., 11, 385-390.
Hashimoto, M. (1968) Glaucophanic metamorphism of the Katsuyama district, Okayama Prefecture, Japan. Jour. Fac. Soi. Univ. Tokyo, Ser. $I I, 17,99-162$.

Hewins, R.H. (1974) Pyroxene crystallization trends and contrasting augite zoning in the Sudbury Nickel Irruptive. Am. Min., 59, 120126.

Ichikawa, K. Murakami, N., Hase, A. and Wadatsumi, K. (1968) Late Mesozoic igneous activity in the Inner Side of Southwest Japan. Pacific Geol., 1, 97-118.

Ishihara, S. (1971) Modal and chemical composition of the granitic rocks related to the major molybdenum and tungsten deposits in the Inner Zone of Southwest Japan. Jour. Geol. Soc. Japan, 77, 441-452.

Kanaya, H. and Ishihara, S. (1973) Regional variation of magnetic susceptibility of the granitic rocks in Japan. Jour. Japan Assoc. Min. Petrol. Econ. Geol., 68, 211-224, (in Japanese with English abstract).

Kinosaki, Y. (1953) On the granitic rocks in Chugoku, and the molybdenite and wolframite deposits in them. Geol. Rep. Hiroshima Univ., 1, 58-75, (in Japanese with English abstract).

Konishi, K. (1954a) The Oniana thrust-the relation between the Sangun metamorphic rocks and the "non-metamorphosed" Palaeozoic formations. Jour. Geol. Soc. Japan, 60, 312. (in Japanese).

- (1954b) Yamaoku Formation (A Jurassic deposit recently discovered in Okayama Prefecture). Jour. Geol. Soc. Japan, 60, 325-332, (in Japanese with English abstract),

Mysen, B.O. and Boettcher, A.L. (1975) Melting of a hydrous mantle: II. Geochemistry of crystals and liquids formed by anatexis of mantle peridotite at high pressures and temperatures as a function of controlled activities of water, hydrogen, and carbon dioxide. Jous. Petrol., 16, 549-593.

Nockolds, S.R. (1954) Average chemical compositions of some igneous rocks. Bull. Geol. Soc. Am. 65, 1007-1032.

Popp, R.K., Gilbert, M.C. and Craig, J.R. (1977) Stability of $\mathrm{Fe}-\mathrm{Mg}$ amphiboles with respect to oxygen fugacity. Am. Min., 62, 1-12.

Reverdatto, V.V. (1970) The facies of contact metamorphism, edited by Sobolev, V.S., translated by Brown, D.A. .Australian National University, $263 \mathrm{p}$.

Sasada, M. (1978) Late Cretaceous-Paleogene intrusive rocks in the Yubara area, Okayama Pref., Southwest Japan. Jour. Geol. Soc. Japan, 84, 23-34, (in Japanese with English abstract), Speidel, D.H. and Osborn, E.F. (1967) Element 
distribution among coexisting phases in the system $\mathrm{MgO}-\mathrm{FeO}-\mathrm{Fe}_{3} \mathrm{O}_{3}-\mathrm{SiO}_{2}$ as a function of temperature and oxygen fugacity. Am. Min., 52, 1139-1152.

Streckeisen, A.L. (1973) Plutonic rocks. Classification and nomenclature recommended by the IUGS subcommission on the systematics of igneous rocks. Geotimes, Oct., 26-30.

Suwa, K., Mizutani, S. and Tsuzuki, Y. (1974) Proposed optical method of determining the twinning laws of plagioclase. Mem. Geol. Sot.
Japan, No. 11, 167-250.

Tainosho, Y. (1974) Geology and petrology of the Ibaragi Granitic Complex in the northern part of Osaka Prefecture, Japan. Jour. Geosciance Osaka City Univ., 17, 53-71.

Wones, D.R. (1966) Mineralogical indicator of relative oxidation states of magmatic systems. Trans. Am. Geophys. Un, 47, 216.

Yamada, S. (1951) Geological sheet map at the scale of 1:75,000, "Kuze". Geol. Surv. Japan.

\section{岡山県湯原南石英ハンレイ岩体の岩石学的研究}

\section{笹 田政 克}

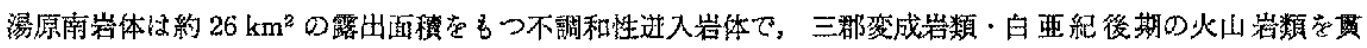
く。本岩体恃石英ハンレイ岩〜カコゥ閏緑岩質の等粒状岩相と主としてトーナル岩〜カコウ閭緑岩質の班状岩相 から構成されておう，前者が岩体内部に，後者が前者索之り囲む形で分布している。現在露出している部分は岩

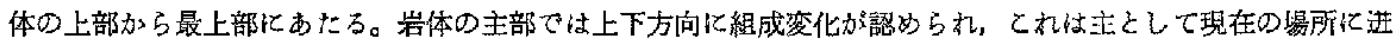

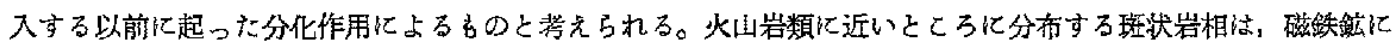

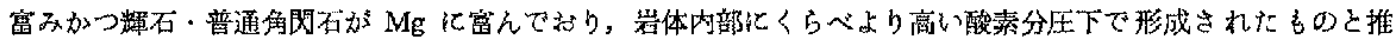
定される。また現在の場所代进入した後も内部で分化作用が進行していたととが，岩体内部に分布するカコウ閉 緑岩・アプライト等加ら推定される。

Hitsugasen 棤ヶ山, Inatsu 禾津, Mikamo 美甘, Mio 見尾, Tainosaka 大井坂 